Article

\title{
Bioleaching of Au-Containing Ore Slates and Pyrite Wastes
}

\author{
Elena B. Daibova 1,2,*, Inna V. Lushchaeva ${ }^{1}$, Victor I. Sachkov ${ }^{1}$, Natalia I. Karakchieva ${ }^{1,2} \mathbb{D}$, \\ Vladislav V. Orlov ${ }^{1, *(\mathbb{D})}$, Rodion O. Medvedev ${ }^{1}\left(\mathbb{D}\right.$, Roman A. Nefedov ${ }^{1}$, Olga N. Shplis ${ }^{3}$ and \\ Natalya I. Sodnam 4
}

1 Innovative Technology Center, National Research Tomsk State University, 36 Lenina Avenue, 634050 Tomsk, Russia; luschaeva@mail.ru (I.V.L.); itc@spti.tsu.ru (V.I.S.); kosovanatalia@yandex.ru (N.I.K.); rodionmedvedev7@gmail.com (R.O.M.); ronef88@yandex.ru (R.A.N.)

2 Siberian Research Institute of Agriculture and Peat, branch of the Siberian Federal Scientific Center of Agro-Bio Technologies of the Russian Academy of Sciences, 3 Gagarina Street, 634050 Tomsk, Russia

3 Pharmacognosy with Courses Botany and Ecology Department, Siberian State Medical University, "SSMU", Tomsk, Moscow Tr., 2B, 634050 Tomsk, Russia; olyazmeewa@yandex.ru

4 Pharmacognosy with Courses Botany and Ecology Department, Tuvan State University “TuvSU”, 36 Lenina street, 667000 Kyzyl, Russia; nsodnam@mail.ru

* Correspondence: edaibova@yandex.ru (E.B.D.); vvorlov92@mail.ru (V.V.O.)

Received: 27 August 2019; Accepted: 18 October 2019; Published: 20 October 2019

check for updates

\begin{abstract}
The influence of the environment and bacterial cultures on the degree of gold leaching from Au-containing raw materials of different compositions, origins, and with different contents of gold, selected in the Ural Federal District (Russia), was determined. The leaching degree was determined according to the change of the gold concentration in the ore by means of mass-spectrometry with inductively-coupled plasma. It was demonstrated that the degree of Au bioleaching from carbonaceous-argillaceous slates, containing $2.17 \mathrm{~g} / \mathrm{t}$ of gold, and from pyritic technogenic raw materials, containing $1.15 \mathrm{~g} / \mathrm{t}$, when holding them in peptone water and Leten medium reached $92.17 \%$ and $87.83 \%$, respectively.
\end{abstract}

Keywords: bioleaching; Au extraction; biotechnology; carbonaceous-argillaceous slates; pyritic technogenic raw material

\section{Introduction}

Nowadays, many deposits of polymetallic ores and nonferrous metals are depleting, and spoils of mineral resource and metallurgy industries are accumulating. Dodson et al. [1], based on the calculations of reserves, consumption and processing of metals established that such elements as $\mathrm{Zn}$, $\mathrm{Ga}, \mathrm{Ge}, \mathrm{As}, \mathrm{Rh}, \mathrm{Ag}$, In, Sn, Sb, Hf and Au would be depleted within 50 years, as well as $\mathrm{Ni}, \mathrm{Cu}, \mathrm{Cd}, \mathrm{Tl}$, and $\mathrm{U}$ within 100 years. Backman [2] estimates that the reserves of such metals as $\mathrm{Cu}, \mathrm{Pb}, \mathrm{Mn}, \mathrm{Ag}$, $\mathrm{Sn}$, and $\mathrm{Zn}$ will be exhausted within 50 years, and $\mathrm{Fe}, \mathrm{Ni}$, and $\mathrm{U}$ in 100 years. Estimates like these emphasize the need for developing new, more efficient methods of extracting metals from natural and technogenic raw materials. At the same time, in today's society, there is a growing need for base and precious metals for electrotechnical, medical industries, and catalyst production.

Owing to the depletion of known gold deposits, there is an acute need for its extraction from natural and technogenic raw materials. Therefore, lean Au-containing carbonaceous-argillaceous slates and Au-containing wastes of ore mining and processing, metallurgical production, including spoils of base ores, mill tailings, slags, and slimes, draw increasingly greater attention as the potential raw materials for the extraction of gold [3-5]. However, traditional pyrometallurgical methods of sulfide 
ore processing pose significant environmental hazards caused by atmospheric emissions of toxic dust and sulfurous gas [6]. Additionally, the conventional technology of cyanide leaching of gold from lean refractory raw materials turns out to be inefficient due to the low content of nonferrous metals and requires considerable capital costs [7]. Biotechnological developments are promising trends in this field and can become a solution to the problem of gold mining. During the last 65 years, different bioleaching technologies have been developed and/or enhanced to extract $\mathrm{Co}, \mathrm{Ni}, \mathrm{Cu}$, and $\mathrm{Zn}[8,9]$ as well as Au [10,11]. They include some new constructions (bioreactors), tested under laboratory and pilot conditions, but are not extensively used in industry [12] during the application of Acidithiobacillus ferrooxidans [13,14], Chromobacterium violaceum [15], Sulfobacillus thermosulfidooxidans, and A. caldus [16]. It is evident that extraction of gold from refractory lean raw materials by means of bioleaching will minimize the harm caused to the environment and make cheaper the processing of sulfide ores and technogenic wastes. Despite the fact that, for different metals, there are certain bioleaching techniques depending on the type of microorganisms, $\mathrm{pH}$, and toxic metals concentration [17], in the literature there is very little information on gold extraction. Therefore, the purpose of the present work is to study the mineral composition of Au-containing raw materials; carbonaceous-argillaceous slates and pyritic technogenic raw materials selected in the Ural Federal District (Russia), as well as the determination of the influence of the bioleaching technique (1—stimulation of the natural microbiome; 2-application of enrichment cultures) and the composition of the nutrient medium on the degree of leaching of gold from Au-containing ores of different compositions, origins, and with different contents of gold.

\section{Materials and Methods}

\subsection{Samples: Au-Containing Ore and Pyrite Wastes}

Au-containing carbonaceous-argillaceous slates (carbonaceous shale) of the Kirovsko-Krylinsk ore-bearing zone (ore slates, Ural Federal District, Orenburg region, Russia) were used as a source of gold. Ore slates were solid argillaceous rock of dark-grey or black color of schistose structure, able to break down into thin plates. Pyrite wastes represented tailings of flotation concentration of sulfide copper-zinc ores (ore slimes of Ural Federal District, Sverdlovsk Region, Russia). Pyritic technogenic raw materials were spherical agglomerates of light-brown color. Samples of ore slates $100 \mathrm{~mm}$ in size were held in stock at $25 \pm 2{ }^{\circ} \mathrm{C}$. Before the experimentation the samples of ore slates were ground in a VKMD-10 vibrating cone mill-crusher (LLC VIBROTECHNIK, St. Petersburg, Russia) up to the fraction with a particle size of $1 \mathrm{~mm}$.

\subsection{Composition and Morphology of Initial and Exposed Samples}

The mineralogical makeup of the ore samples with a particle size of $1 \mathrm{~mm}$ was determined by X-ray structural analysis using a D2 PHASER powder diffraction apparatus (Bruker, Berlin, Germany) (X-ray generator: $30 \mathrm{~kW} / 10 \mathrm{ma}$; the angular range was from 3 to $160^{\circ}$ 2Theta, the peak positional accuracy was $\pm 0.02^{\circ}$ in the measuring range allowing detection of the presence of the mineral phase in the mixture under study at a level of $0.5 \%$ ).

The sample's morphology was studied by means of a Hitachi S-3400N electron microscope (Hitachi, Tokyo, Japan). The microscope was equipped with an X Flash 4010 energy-dispersive attachment (Bruker, Berlin, Germany), which was used for determining the elemental composition of ores using the energy-dispersive method (energy dispersive spectroscopy (EDS)), allowing the determination of the content of chemical elements from $\mathrm{Li}$ to $\mathrm{U}$ with a concentration of more than 0.1 mass (\%), as well as studying the nature of their spatial distribution in the matrix under study.

The Au concentration in the samples composition $(\mathrm{g} / \mathrm{t})$ before and after leaching was determined using mass-spectroscopy with inductively-coupled plasma on a ICP-MS ELAN-9000 DRC-e mass spectrometer (Perkin Elmer, Waltham, MA, USA). According to the procedure, $10 \mathrm{~g}$ of the sample was preliminary subjected to wet combustion at $450{ }^{\circ} \mathrm{C}$ with subsequent spraying of the obtained solution into plasma of the inductively-coupled discharge. The calibration curve of Au was built within the 
range of $0.0000001-0.0035$ mass (\%). The obtained concentration was used for the calculation of the bioleaching degree as a difference between the initial and final concentration of gold in the ore, in \%.

\subsection{Bioleaching Test}

Bioleaching of gold from the ore was carried out applying the fraction $1.0 \pm 0.01 \mathrm{~mm}$ in size using two methods: (1) stimulating the natural microbiome of carbonaceous-argillaceous slates (CAS) and pyritic raw materials and (2) applying enrichment cultures, obtained using different nutrient media from carbonaceous-argillaceous slates.

In the first case, three nutrient media were prepared for ore exposition: (1) peptone water (PW) (tap water containing $2.50 \pm 0.1 \mathrm{~g} / \mathrm{L}$ of bacto-peptone); (2) PW30 medium for bacteria, leaching gold [18] and consisted $(\mathrm{g} / \mathrm{L}): \mathrm{K}_{2} \mathrm{HPO}_{4}-5.0 ; \mathrm{MgSO}_{4} * 7 \mathrm{H}_{2} \mathrm{O}-2.5 ; \mathrm{NaCl}-2.5 ; \mathrm{Fe}_{2}\left(\mathrm{SO}_{4}\right)_{3}-0.05 ; \mathrm{MnSO}_{4}-0.05$ and Vinogradsky solution $-0,05 \mathrm{~mL} / \mathrm{L}$; and (3) Leten medium $(\mathrm{LM})(\mathrm{g} / \mathrm{L}):\left(\left(\mathrm{NH}_{4}\right)_{2} \mathrm{SO}_{4}-0.15 ; \mathrm{KCl}-0.05\right.$; $\mathrm{MgSO}_{4} * 7 \mathrm{H}_{2} \mathrm{O}-5.0 ; \mathrm{KH}_{2} \mathrm{PO}_{4}-0.1 ; \mathrm{Ca}\left(\mathrm{NO}_{3}\right)_{2} \mathrm{P}-0.01$ and $10 \%$-solution of $\mathrm{FeSO}_{4}-10 \mathrm{~mL} / \mathrm{L}$.

All the media were prepared and sterilized before using. The ore was held in the prepared media in the $250 \mathrm{~mL}$ glass bulbs ( $100 \mathrm{~mL}$ of the medium, containing $10 \mathrm{wt} \%$ of ore particles) at $25 \pm 0.5^{\circ} \mathrm{C}$ without stirring during 50 days. After holding, the samples were centrifuged at a rate of $2500 \mathrm{rev} / \mathrm{min}$ for $10 \mathrm{~min}$ in an Eppendorf AG 22331 centrifuge (Eppendorf, Hamburg, Germany), the test tube volume was $50 \mathrm{~mL}$. The precipitate was dried in a Sanyo MIR-154 air bath oven (Sanyo, Osaka, Japan) at $45 \pm 0.5^{\circ} \mathrm{C}$ for $24 \mathrm{~h}$, whereupon the elemental composition of the rock was determined.

The method of stimulating the bacteria that inhabit the ores under study allows performing biotechnological works on bioleaching of $\mathrm{Au}$ from the ore within a shorter period of time as there is no need to obtain pure cultures or bacteria consortiums.

In the second case, enrichment cultures (bacteria consortiums) were obtained by placing the ore (CAS) in the nutrient media of the following compositions: (1) peptone water (PW); (2) PW30 medium for the bacteria that leach $\mathrm{Au}$ (Pare, 1968). Enrichment cultures were cultivated in the air bath oven at a temperature of $25 \pm 0.5^{\circ} \mathrm{C}$ without stirring for 30 days; $\mathrm{pH}$ was 4.5 . The enrichment culture obtained using PW is hereafter denoted as G1; in PW30 medium, G2. The obtained enrichment cultures were cultivated and stored on the corresponding media.

Au bioleaching under the influence of enrichment cultures G1 and G2 was studied in the $500 \mathrm{~mL}$ glass bulbs with $200 \mathrm{~mL}$ of the PW30 nutrient medium, containing 10\% $(v / v)$ of the milled ore. Each bulb was inoculated by the cell-rich fluid of the corresponding enrichment culture (G1 or G2) in an amount of $5 \%(v / v)$. The bulbs were incubated at $25 \pm 0.5{ }^{\circ} \mathrm{C}$ without stirring for 28 days.

To study the elemental composition of the rock and the process liquor, the samples were centrifuged at a rate of $2500 \mathrm{rev} / \mathrm{min}$ for $10 \mathrm{~min}$ on an Eppendorf AG 22331 centrifuge (Eppendorf, Hamburg, Germany), and the volume of the test tube was $50 \mathrm{~mL}$. The precipitate was dried in a Sanyo MIR-154 air bath oven (Japan) at $45 \pm 0.5^{\circ} \mathrm{C}$ for $24 \mathrm{~h}$.

\subsection{Microbial Community Structure Analysis}

Total DNA was extracted from the G1 and G2 enrichment cultures and the generic composition of the bacteria consortium was determined by sequencing when synthesizing amplicons of the $16 \mathrm{~S}$ rRNA gene of prokaryotic organisms and subsequent bioinformatical processing of the data obtained. The amplicons of the 16S rRNA gene were obtained by PCR amplification using total DNA specimens of microbial communities of the assays.

The V3-V4 region of the 16S rRNA gene was amplified from the DNA specimen by PCR using primers universal for all prokaryotes. The amplicons, obtained here due to the presence of technical sequences on the $5^{\prime}$ ends of primers, can be sequenced on an IlluminaMiSeq platform after purification.

To obtain amplicons, the following primer set was used: the forward primer (5'-CAAGCAGA AGACGGCATACGAGATGTGACTGGAGTTCAGACGTGTGCTCTTCCGATCT XXXXXXXXXXXX ZZZZ CCTAYGGGDBGCWSCAG-3') consisting, respectively, of " 5 ' Illumina Linker Sequence", "Index 1", "Heterogeneity Spacer" [19], and the Pro-mod-341F primer sequence [20]; the reverse primer 
(5'-AATGATACGGCGACCACCGAGATCTACACTCTTTCCCTACACGACGCTCTTCCGATCT XX XXXXXXXXXX ZZZZGACTACNVGGGTMTCTAATCC-3") consisting of " 3 ' Illumina Linker Sequence", "Index 2", "Heterogeneity Spacer", and the Pro-mod-805R primer sequence [20], respectively. The obtained amplicons were divided in the $2 \%$ agarose gel by means of electrophoresis; they were cut from the gel with a scalpel and cleaned using a Cleanup Standard kit (Evrogen, Russia). The sequencing was performed on a MiSeq system (Illumina, San Diego, CA, USA) using a set of reagents providing a reading length of 300 nucleotides from each end of the amplicon. Demultiplexing was performed by means of the corresponding QIIME software scripts of the 1.9.0 version [21]. Subsequent processing and sequences analysis were also conducted in the QIIME software, version 1.9.0. The data were infiltrated with a minimum reading quality of nucleotide equal to 30 and a minimum length of reading of $300 \mathrm{bp}$. The readings were checked for chimericalness by means of the identify_chimeric_seqs.py script using the USEARCH algorithm of the 6.1544 version [22] and the reference reading base of $16 \mathrm{~S}$ rRNA Silva 123 [23]. The OTE table was formed by means of the pick_open_reference_otus.py script. The sequences were grouped in OTE with a similarity level of 97\% [24] using the USEARCH algorithm, version 6.1544 [22], and the reference reading base of 16S rRNA Silva, version 123 [24]. The alpha diversity was analyzed and saturation curves were constructed by means of the core_diversity_analyses.py script for a normalized sample of 170,000 readings per sample.

\section{Results and Discussion}

\subsection{Composition of Initial Ores}

According to the data (Figure 1) of the X-ray structural analysis, argillaceous minerals of the illite type $(61.1 \%$, hydrated in a varying degree by muscovite $(16 \%)$, as well as quartz $(11 \%$, Table 1), clinochlore 1M1 (chlorate) dominates in the sample composition of carbonaceous-argillaceous slates. There is zeolite in the trace quantities. On the whole, the rock can be diagnosed as quartzhydrosericite-kaolinite-illite argillite or as quartz-hydrosericite-argillaceous slate.

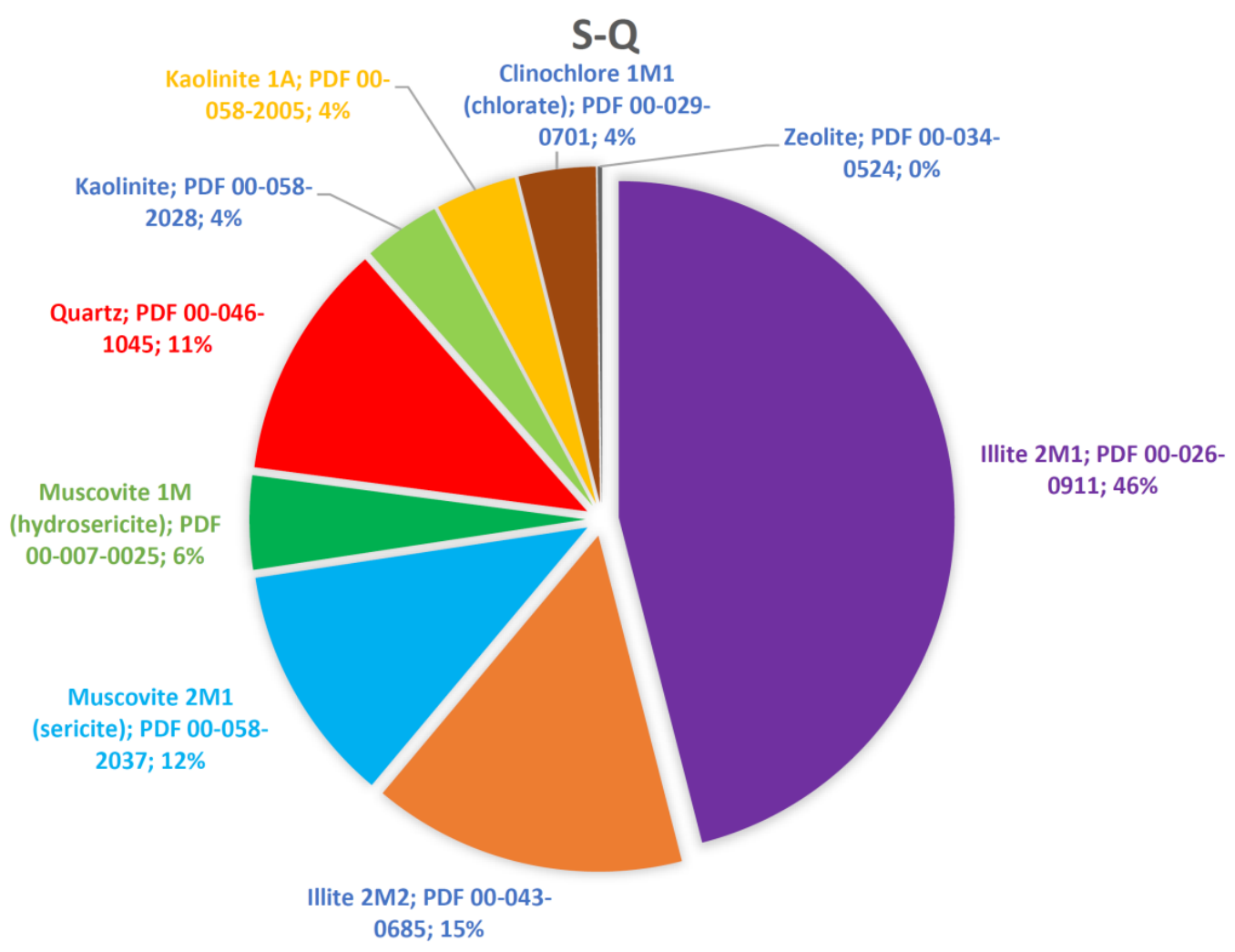

Figure 1. The diagram of the composition of rock-forming minerals of the initial ore sample. 
Table 1. Rock-forming minerals in the ore slate sample.

\begin{tabular}{ccc}
\hline No. & Mineral, Composition & Phase Content, wt/vol \% \\
\hline 1 & Illite 2M1 & 46 \\
2 & Illite 2M2 & 15.1 \\
3 & Muscovite 2M1 (sericite) & 11.5 \\
4 & Muscovite 1M (hydrosericite) & 4.5 \\
5 & Quartz & 11.4 \\
6 & Kaolinite & 3.7 \\
7 & Kaolinite 1A & 3.9 \\
8 & Clinochlore 1M1 (chlorate) & 3.7 \\
9 & Zeolite & 0.2 \\
\hline
\end{tabular}

The analysis of the ore mineral composition using a Hitachi S-3400N electron microscope allowed establishing the presence in slates of 12 micromineral phases (Table 2) up to one micron in size. The list of the identified micromineral phases is presented in Table 2; the general view and the evidence diagnostic base are shown in Figures 2-4.

Table 2. Micromineral phases and their elemental composition in the sample of carbonaceousargillaceous slates.

\begin{tabular}{|c|c|c|c|c|c|}
\hline Mineral & Element & Content, \% & Mineral & Element & Content, $\%$ \\
\hline \multirow{2}{*}{ Pyrite } & $\mathrm{Fe}$ & 41.2 & \multirow{2}{*}{$\begin{array}{l}\text { Tin-containing phase } \\
\text { (cassiterite) }\end{array}$} & Sn & 47.1 \\
\hline & $S$ & 51.7 & & $\mathrm{~S}$ & 0.3 \\
\hline \multirow{2}{*}{ Marcasite } & $\mathrm{Fe}$ & 47.8 & \multirow{2}{*}{$\begin{array}{l}\text { Lead-containing phase } \\
\quad \text { (yellow lead) }\end{array}$} & $\mathrm{Pb}$ & 44.0 \\
\hline & S & 46.0 & & S & 3.4 \\
\hline \multirow{3}{*}{$\begin{array}{l}\text { Ferrous arsenide } \\
\text { (loellingite) }\end{array}$} & As & 28.9 & \multirow{3}{*}{ Chalcopyrite } & $\mathrm{Cu}$ & 29.2 \\
\hline & $\mathrm{Fe}$ & 30.0 & & $\mathrm{Fe}$ & 25.4 \\
\hline & $S$ & 0.6 & & $S$ & 26.2 \\
\hline \multirow{3}{*}{$\begin{array}{l}\text { Tungsten-containing } \\
\text { phase (wolframite) }\end{array}$} & W & 59.8 & \multirow{3}{*}{ Zircon } & $\mathrm{Zr}$ & 37.5 \\
\hline & $\mathrm{Ti}$ & 3.2 & & $\mathrm{Si}$ & 7.3 \\
\hline & $\mathrm{Fe}$ & 1.7 & & $\mathrm{O}$ & 53.8 \\
\hline \multirow{3}{*}{$\begin{array}{c}\text { Native } \\
\text { copper-bearing gold }\end{array}$} & $\mathrm{Au}$ & 49.6 & \multirow{3}{*}{ Barite } & $\mathrm{Ba}$ & 44.8 \\
\hline & $C_{1}$ & 17 & & $\mathrm{~S}$ & 10.5 \\
\hline & e & 1.7 & & $\mathrm{Ca}$ & 1.2 \\
\hline \multirow{6}{*}{$\begin{array}{l}\text { Indium-containing } \\
\text { phase (indium } \\
\text { hydroxide with } \\
\text { chlorine) }\end{array}$} & In & 44.2 & \multirow{6}{*}{ Monazite } & $\mathrm{P}$ & 12.3 \\
\hline & $\mathrm{Cl}$ & 4.0 & & $\mathrm{La}$ & 10.8 \\
\hline & $\mathrm{Fe}$ & 0.4 & & $\mathrm{Ce}$ & 20.4 \\
\hline & \multirow{3}{*}{ S } & \multirow{3}{*}{0.2} & & $\mathrm{Nd}$ & 9.6 \\
\hline & & & & $\mathrm{Sm}$ & 0.3 \\
\hline & & & & Th & 3.9 \\
\hline
\end{tabular}



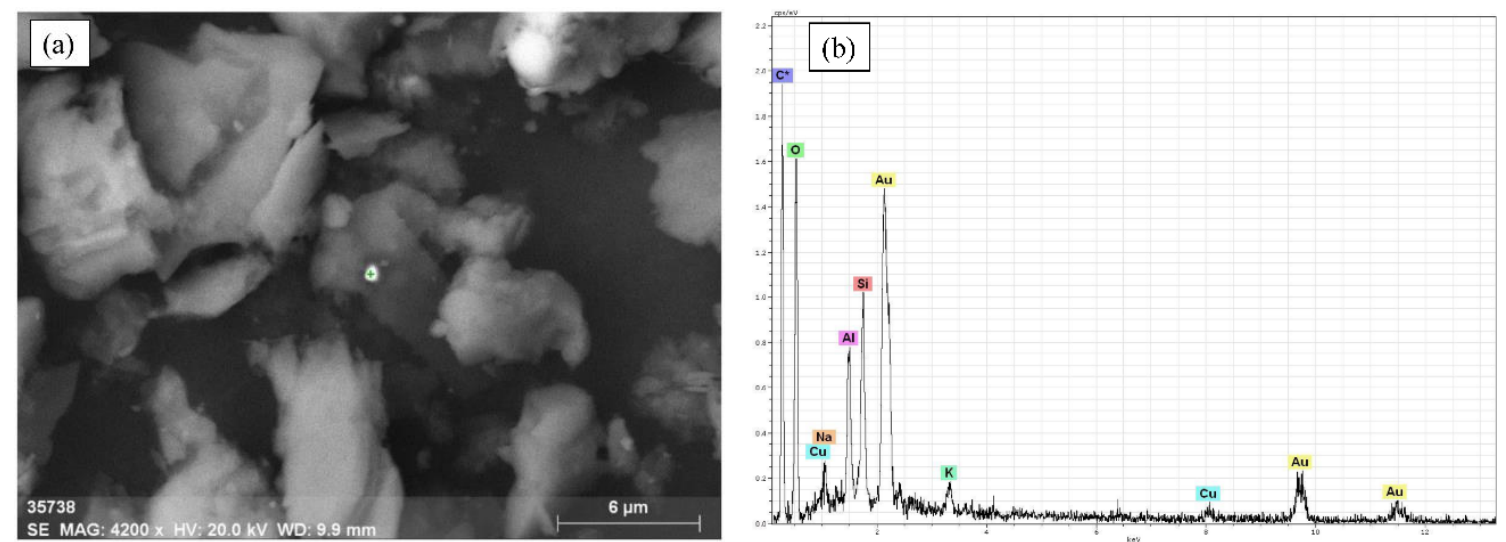

Figure 2. (a) SEM image of ore slates. The Au phase, containing copper, is marked; (b) energy-dispersive spectrum of the mentioned area.
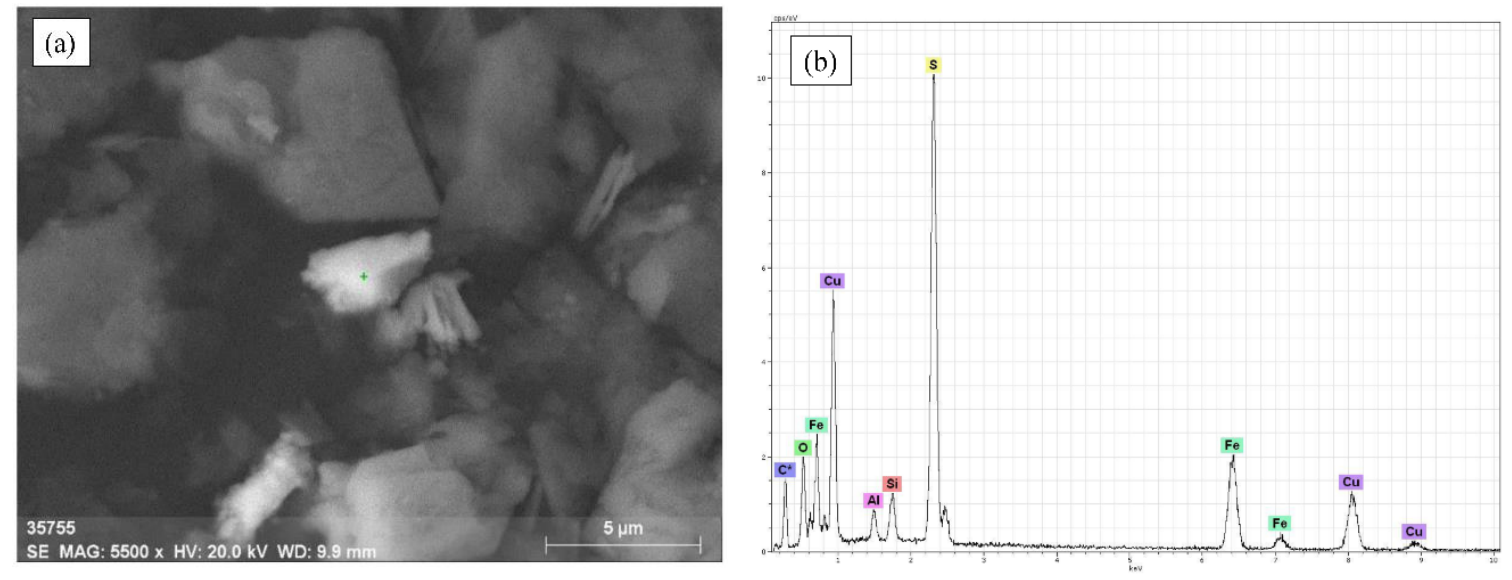

Figure 3. (a) SEM image of ore slates. The phase of copper and iron sulfide (chalcopyrite) is marked; (b) energy-dispersive spectrum.
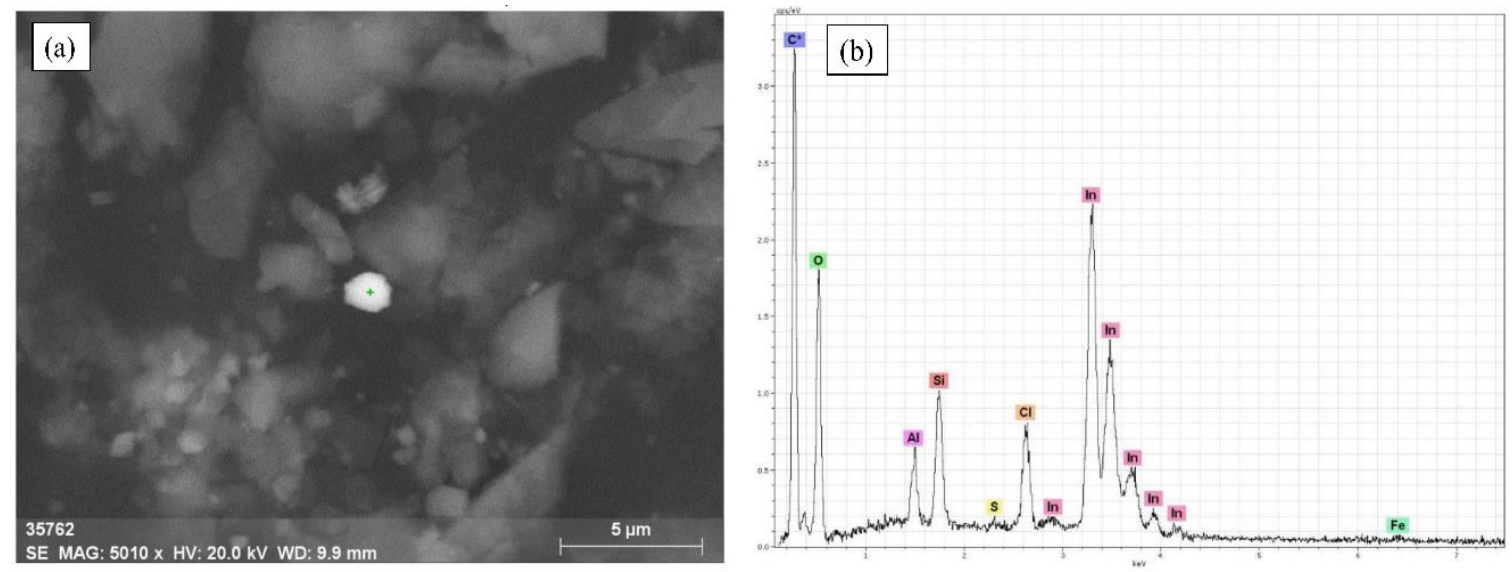

Figure 4. (a) SEM image of ore slates. The In-containing phase with chlorine and sulfur is marked; (b) energy-dispersive spectrum of the marked point.

Analysis of the research results showed that $\mathrm{Au}$, found in the sample, was in a free native form (Figure 2). It was in association with pyrite, marcasite, and ferrous arsenide of the loellingite type, but not arsenic pyrite, which could be a positive sign of the absence of the bound Au in sulfides. In addition to these sulfides, chalcopyrite (Figure 3), a rare form of $\mathrm{Pb}$ oxide of the yellow lead type were identified, which, probably, could be evidence of the development of the oxidation zone. Identification of the In-containing phase was a highly interesting discovery, especially in the association with chlorine 
(Figure 4). Its discovery may bear evidence of high probabilities of identifying resources of trace elements $\mathrm{In}, \mathrm{Ga}$, and $\mathrm{Ge}$ and requires special study.

In their elemental composition ore slates are alumosilicate rock with a higher content of potassium $(3.2 \%)$, iron $(3.1 \%)$, sodium and sulfur $(1.2 \%$, Table 3$)$. In view of the specificity of the applied analytical method, carbon was not identified, but no more than $7 \%$ fell to its share. The high content of sulfur and iron in rock suggested the presence of iron sulfide at the level of $0.1-0.2 \%$. Pyrite wastes were represented to a greater degree by iron sulfide with the increased content of silicon (8.6\%), magnesium $(4.2 \%)$, calcium $(2.9 \%)$, and aluminum $(2.6 \%)$ (Table 3$)$.

Table 3. Elemental composition of ore slates and pyrite wastes.

\begin{tabular}{|c|c|c|c|c|c|}
\hline \multirow{3}{*}{ Element } & & & \multirow{3}{*}{ Element } & \multicolumn{2}{|c|}{ ICP-MS } \\
\hline & \multicolumn{2}{|c|}{ Content, wt $\%$} & & \multicolumn{2}{|c|}{ Content, g.ton ${ }^{-1}, \mathrm{~g} / \mathrm{t}$} \\
\hline & Ore Slates & Pyrite Wastes & & Ore Slates & Pyrite Wastes \\
\hline $\mathrm{Si}$ & 20.4 & 8.6 & $\mathrm{Au}$ & 2.17 & 1.15 \\
\hline $\mathrm{Al}$ & 13.4 & 2.6 & $\mathrm{Ag}$ & 0.5 & 13.6 \\
\hline $\mathrm{K}$ & 3.2 & - & $\mathrm{Cu}$ & 160 & 1200 \\
\hline $\mathrm{Fe}$ & 3.1 & 36.9 & $\mathrm{Zn}$ & 31.7 & 1500 \\
\hline $\mathrm{Na}$ & 1.3 & - & As & 948 & 1400 \\
\hline S & 1.2 & 24.1 & $\mathrm{Sb}$ & 58.9 & 57 \\
\hline $\mathrm{Ca}$ & 0.3 & 2.9 & $\mathrm{~Pb}$ & 5.08 & 380 \\
\hline $\mathrm{O}$ & 57.0 & 20.6 & In & 5.76 & 2 \\
\hline $\mathrm{Mg}$ & - & 4.2 & & & \\
\hline $\mathrm{C}$ & 7.0 & - & $\mathrm{Ge}$ & 4.85 & 1.5 \\
\hline
\end{tabular}

ISP-MS data allowed identifying some geochemical peculiarities of the slates under study, manifesting themselves in the increased content of arsenic, copper, antimony, nickel and zinc. It was established that one ton of slates included up to $2.2 \mathrm{~g}$ of $\mathrm{Au}$, and up to $1.15 \mathrm{~g}$ of pyrite (Table 3). Therefore, the samples under study can be classified as lean Au-containing ores.

\subsection{Bioleaching Bacteria}

According to the data of the DNA analysis (Figure 5), the largest share in the G1 consortium fell to the representatives of Pseudomonas sp. (68\%). In addition, bacteria Bacillus sp. (17\%) and Stenotrophomonas sp. (14\%) were present. Representatives of Acidiplasma sp. were found in an insignificant amount $(0.5 \%)$. As is well known, bacteria of Pseudomonas are able to deactivate carbonaceous components and, thus, can increase Au bioleaching $[25,26]$.

Additionally, it is common knowledge that many kinds of Pseudomonas species are cyanogens. Cyanidation is one of the most widely used technologies to extract gold from mineral ores. Cyanide is not considered as a persistent pollutant, but its wide application leads to its accumulation in large quantities in the environment and poses a danger to different biological objects [27]. To minimize such risks, the biocyanidation process becomes of particular importance. A number of researchers defined different cyanogenetic bacteria, fungi, and archaea found in different sources of the environment to extract Au from mineral ores. Among the Pseudomonas bacteria, there are many species possessing cyanogenetic properties, for example, $P$. fluorescens, $P$. aureofaciens, $P$. aeruginosa, $P$. plecoglossicida, P. putida, and P. syringae [28-31].

The G2 enrichment culture consisted of only Micrococcus sp. bacteria $(100 \%)$; the share of undetermined bacteria was $0.008 \%$. However, just the addition of this culture showed the best leaching of $\mathrm{Au}$ from CAS. 


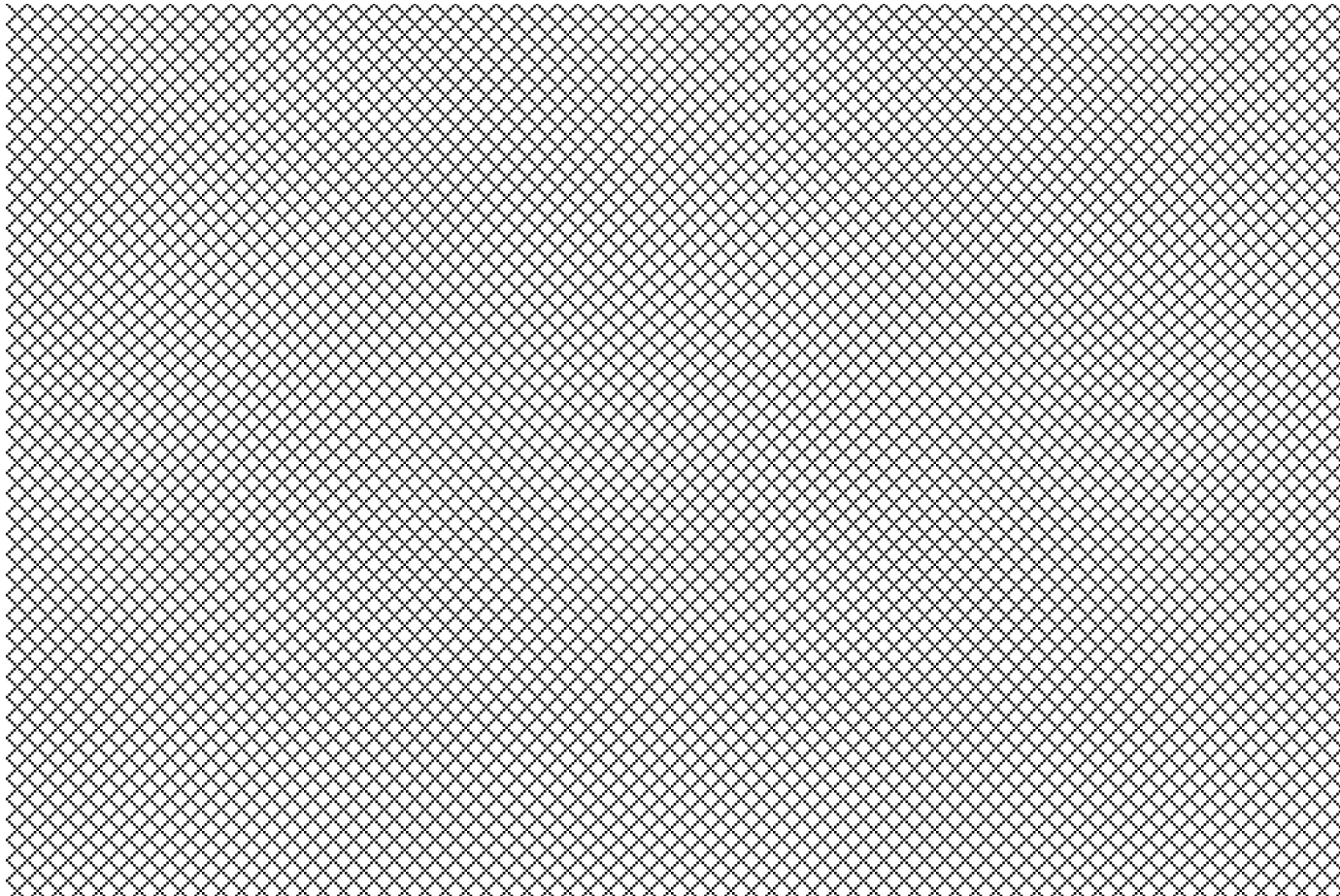

Figure 5. The composition of enrichment bacterial culture G1.

\subsection{Bioleaching Results}

It was established that the Au concentration in CAS after leaching decreased from 9.8 to 2.8 times (Figure 6, Table 4) in different variants of the experiment (by stimulating the natural microbiome and by applying enrichment cultures). However, the leaching method did not influence significantly the change in the rate of extracting Au from the studied ores. The maximum degree of Au leaching $(92.17 \%)$ was reached when holding CAS in the PW medium (stimulation of the natural microbiome) whereas the differences in the compositions of PW30 and LM media did not affect the bioleaching degree $(90.32 \%)$.

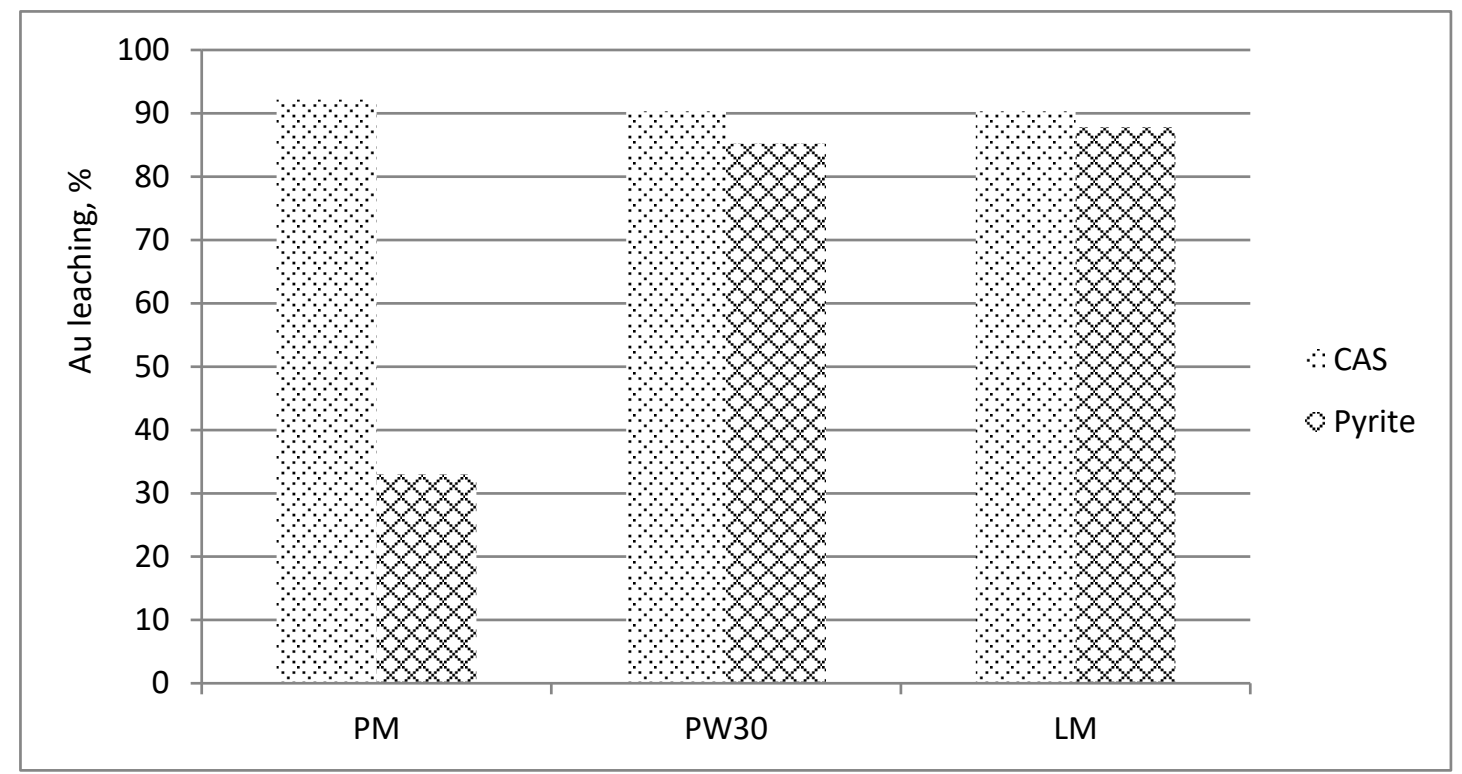

Figure 6. Au leaching from CAS and pyrite. 
Table 4. Au bioleaching from CAS and pyrite technogenic raw materials.

\begin{tabular}{ccccccc}
\hline \multicolumn{7}{c}{ Au content in the Ore after Experimenting, $\mathbf{g} / \mathbf{t}$} \\
\hline \\
\hline CAS & initial & PW & PW30 & LM & G1 & G2 \\
\hline Pyrite & $2.17 \pm 0.06$ & $0.17 \pm 0.005$ & $0.21 \pm 0.006$ & $0.21 \pm 0.006$ & $0.22 \pm 0.006$ & $0.19 \pm 0.006$ \\
\hline
\end{tabular}

When bioleaching $\mathrm{Au}$ from CAS, the enrichment bacteria cultures established that the G2 consortium (91.24\%) showed better bioleaching as compared to that of the G1 consortium $(89.86 \%)$ (Table 4). Perhaps such a small advantage of the G2 consortium is connected with the fact that, initially, this consortium was obtained on the PW30 medium, on which bioleaching was carried out.

In the experiments on Au bioleaching from pyritic technogenic raw materials by stimulating the natural microbiome, the Au concentration in the ore decreased from 1.5 to 8 times in comparison with the initial $\mathrm{Au}$ content in the ore. However, the leaching degree strongly depended on the choice of the nutrient medium (Figure 6). The rate of extraction increased amongst the used PW ... PW30 ... LM media and amounted to $33.04 \%, 85.22 \%$, and $87.83 \%$, respectively. The obtained data could be explained by the composition of nutrient media. The PW nutrient media consisted of peptone water, but allegedly to promote the growth of bacteria, inhabiting the pyrite surface, inorganic components were required that were insufficient in pyrite, or they were in a form inaccessible for bacteria. Such components were included in the composition of PW30 and LM nutrient media, which explained the best growth of bacteria, representatives of the microbiome of pyritic technogenic raw materials, and, as a consequence, the best leaching of Au from pyrite. Supposedly, the composition of the natural microbiome of the ore, used in the experiment, includes cyanogenetic bacteria that are capable to carry out gold bioleaching. This is confirmed by the fact that the composition of the G1 consortium has representatives of Pseudomonas species, among which there are many cyanogens [28-31].

As a result of the experiments made it was established that the method of stimulating the natural microbiome allowed achieving the maximum degree of bioleaching for both ores. It was obvious that, for each type of the ores, selecting an optimal composition of the nutrient medium for better $\mathrm{Au}$ leaching was required, taking into account the initial elemental composition of the ores.

\section{Conclusions}

The mineral composition was studied and it was shown that the main components of the country rock of carbonaceous-argillaceous slates were argillaceous minerals of the illite-2M1, 2M2 type. The intermediate grade of $\mathrm{Au}$ was $2.20 \mathrm{~g} / \mathrm{t}$. Au found in the sample was in a free native form. It was in association with pyrite, marcasite, and arsenide of iron of the loellingite type, but not with the phase of arsenic pyrite, which could be a good evidence of the absence of the bound Au in sulfides.

The composition of pyritic technogenic raw materials to a greater degree was represented by iron sulfide with an increased content of silicon (8.6\%), magnesium (4.2\%), calcium (2.9\%), and aluminum (2.6\%). The intermediate grade of Au was $1.15 \mathrm{~g} / \mathrm{t}$.

At present the methods of bioleaching of gold from ores using basically known acidophilic bacteria, which were extracted from different sources, or the use of microbial consortia of acidophilic bacteria are widely applied [13-16,32]. Before using such bacteria there must be time for their adaptation to new conditions. We offer a new approach-stimulating of the natural microbiome. This will allow a significant reduction in the laboratory part of the biotechnology since there is no need to carry out the adaptation of bacteria that are traditionally used in gold bioleaching. It is also necessary to take into account that the bacteria introduced from the outside are competitors for the natural microbiome. When stimulating the natural microbiome, it is necessary to take into account the composition of the ore itself to select an optimal composition of the nutrient medium added to the ore to initiate the bioleaching processes. 
Basing on the obtained results, during establishing the biotechnology of Au bioleaching from Au-containing carbonaceous-argillaceous slates of the ore-bearing zone and pyritic technogenic raw materials, it becomes possible to orient towards the creation of optimal conditions for development of the natural microbiome of the ores to obtain the maximum bioleaching of Au from the ore.

Author Contributions: Conceptualization: E.B.D., I.V.L., V.I.S., and N.I.K.; data curation: E.B.D., V.I.S., N.I.K., and R.O.M.; formal analysis: V.V.O., R.O.M., O.N.S., and N.I.S.; investigation: E.B.D., I.V.L., V.V.O., R.O.M., R.A.N., O.N.S., and N.I.S.; methodology: E.B.D., I.V.L., and V.I.S.; project administration: E.B.D., V.I.S., N.I.K., and R.A.N.; resources: V.I.S.; supervision: V.I.S.; writing—original draft: E.B.D., V.V.O., and R.O.M.

Funding: This research was funded by Ministry of Education and Science of the Russian Federation, project No. 10.3031.2017/4.6 and with the support of the Tomsk State University Competitiveness Enhancement Program.

Acknowledgments: The results were obtained as part of the fulfillment of the state task of the Ministry of Education and Science of the Russian Federation, project no. 10.3031.2017/4.6 and with the support of the Tomsk State University Competitiveness Enhancement Program.

Conflicts of Interest: The authors declare no conflict of interest.

\section{References}

1. Dodson, J.; Hunt, A.; Parker, H.; Yang, Y.; Clark, J.; Dodson, J.; Hunt, A. Elemental sustainability: Towards the total recovery of scarce metals. Chem. Eng. Process. Process. Intensif. 2012, 51, 69-78. [CrossRef]

2. Backman, C.-M. Global supply and demand of metals in the future. J. Toxicol. Environ. Heal. Part A 2008, 71, 1244-1253. [CrossRef] [PubMed]

3. Muravyov, M.I.; Fomchenko, N.V. Biohydrometallurgical treatment of old flotation tailings of sulfide ores containing non-nonferrous metals and gold. Miner. Eng. 2018, 122, 267-276. [CrossRef]

4. Karmazin, V.; Krylov, I.; Sysa, P.; Frolov, M. Rational Methods of Concentration of Small, Thin, Finely Dispersed and Colloidal Gold of Technogenic Waste Deposits Will Ryveem. Ecol. Ind. Russ. 2018, 22, 11-17. [CrossRef]

5. Khaliq, A.; Rhamdhani, M.; Brooks, G.; Masood, S. Metal extraction processes for electronic waste and existing industrial routes: A review and australian perspective. Resources 2014, 3, 152-179. [CrossRef]

6. Levenets, O.; Khaynasova, T.; Balykov, A. The kinetics of bacterial-chemical leaching of sulfide ore in the pilot continuous bioreactor system at three different flow rates. Adv. Curr. Nat. Sci. 2018, 6, 96-101. [CrossRef]

7. Sajjad, W.; Zheng, G.; Din, G.; Ma, X.; Rafiq, M.; Xu, W. Metals Extraction from Sulfide Ores with Microorganisms: The Bioleaching Technology and Recent Developments. Trans. Indian Inst. Met. 2019, 72, 559-579. [CrossRef]

8. Watling, H.; Collinson, D.; Fjastad, S.; Kaksonen, A.; Li, J.; Morris, C.; Perrot, F.; Rea, S.; Shiers, D.; Rea, S. Column bioleaching of a polymetallic ore: Effects of $\mathrm{pH}$ and temperature on metal extraction and microbial community structure. Miner. Eng. 2014, 58, 90-99. [CrossRef]

9. Pakostova, E.; Grail, B.M.; Johnson, D.B. Indirect oxidative bioleaching of a polymetallic black schist sulfide ore. Miner. Eng. 2017, 106, 102-107. [CrossRef]

10. Das, S.; Ting, Y.-P.; Ting, Y. Improving Gold (Bio)Leaching Efficiency Through Pretreatment Using Hydrogen Peroxide Assisted Sulfuric Acid. CLEAN-Soil Air Water 2017, 45, 1500945. [CrossRef]

11. Bouzalakos, S.; Dudeney, A.; Chan, B. Leaching characteristics of encapsulated controlled low-strength materials containing arsenic-bearing waste precipitates from refractory gold bioleaching. J. Environ. Manag. 2016, 176, 86-100. [CrossRef] [PubMed]

12. Watling, H.R. Review of Biohydrometallurgical Metals Extraction from Polymetallic Mineral Resources. Minerals 2014, 5, 1-60. [CrossRef]

13. Kondrat'Eva, T.F.; Pivovarova, T.A.; Krylova, L.N.; Melamud, V.S.; Adamov, E.V.; Karavaiko, G.I. Leaching of copper ore of the Udokanskoe deposit at low temperatures by an association of acidophilic chemolithotrophic microorganisms. Appl. Biochem. Microbiol. 2011, 47, 520-526. [CrossRef]

14. Shin, D.; Jeong, J.; Lee, S.; Pandey, B.D.; Lee, J.-C. Evaluation of bioleaching factors on gold recovery from ore by cyanide-producing bacteria. Miner. Eng. 2013, 48, 20-24. [CrossRef]

15. Natarajan, G.; Ting, Y.-P. Pretreatment of e-waste and mutation of alkali-tolerant cyanogenic bacteria promote gold biorecovery. Bioresour. Technol. 2014, 152, 80-85. [CrossRef] 
16. Muravyov, M.I.; Bulaev, A.G. Two-step oxidation of a refractory gold-bearing sulfidic concentrate and the effect of organic nutrients on its biooxidation. Miner. Eng. 2013, 45, 108-114. [CrossRef]

17. Potysz, A.; Van Hullebusch, E.D.; Kierczak, J. Perspectives regarding the use of metallurgical slags as secondary metal resources-A review of bioleaching approaches. J. Environ. Manag. 2018, 219, 138-152. [CrossRef]

18. Pare, I. Bacterial leaching of Au. Biological study of this phenomenon and a problem of practical application. In Proceedings of the VIII International Mineral Processing Congress, Leningrad, USSR, 10-15 June 1968.

19. Fadrosh, D.W.; Ma, B.; Gajer, P.; Sengamalay, N.; Ott, S.; Brotman, R.M.; Ravel, J. An improved dual-indexing approach for multiplexed 16S rRNA gene sequencing on the Illumina MiSeq platform. Microbiome 2014, $2,6$. [CrossRef]

20. Merkel, A.Y.; Pimenov, N.V.; Rusanov, I.I.; Slobodkin, A.I.; Slobodkina, G.B.; Tarnovetckii, I.Y.; Frolov, E.N.; Dubin, A.V.; Perevalova, A.A.; Bonch-Osmolovskaya, E.A. Microbial diversity and autotrophic activity in Kamchatka hot springs. Extremophiles 2016, 21,307-317. [CrossRef]

21. Caporaso, J.G.; Kuczynski, J.; Stombaugh, J.; Bittinger, K.; Bushman, F.D.; Costello, E.K.; Fierer, N.; Pena, A.G.; Goodrich, J.K.; Gordon, J.I.; et al. QIIME allows analysis of high-throughput community sequencing data. Nat. Methods 2010, 7, 335-336. [CrossRef]

22. Edgar, R.C. Search and clustering orders of magnitude faster than BLAST. Bioinformatics 2010, 26, $2460-2461$. [CrossRef] [PubMed]

23. Quast, C.; Pruesse, E.; Yilmaz, P.; Gerken, J.; Schweer, T.; Yarza, P.; Peplies, J.; Glöckner, F.O. The SILVA ribosomal RNA gene database project: Improved data processing and web-based tools. Nucleic Acids Res. 2012, 41, D590-D596. [CrossRef] [PubMed]

24. Schloss, P.D.; Handelsman, J. Toward a Census of Bacteria in Soil. PLoS Comput. Boil. 2006, 2, e92. [CrossRef] [PubMed]

25. Kulpa, C.F.; Brierley, J. Microbial deactivation of preg-robbing carbon in gold ore. Biohydrometall. Technol. 1993, 1, 427-435.

26. Ofori-Sarpong, G.; Tien, M.; Osseo-Asare, K. Myco-hydrometallurgy: Coal model for potential reduction of preg-robbing capacity of carbonaceous gold ores using the fungus, Phanerochaete chrysosporium. Hydrometallurgy 2010, 102, 66-72. [CrossRef]

27. Hilson, G.; Monhemius, A.; Monhemius, A. Alternatives to cyanide in the gold mining industry: What prospects for the future? J. Clean. Prod. 2006, 14, 1158-1167. [CrossRef]

28. Askeland, R.A.; Morrison, S.M. Cyanide production by Pseudomonas fluorescens and Pseudomonas aeruginosa. Appl. Environ. Microbiol. 1983, 45, 1802-1807.

29. Flaishman, M.A. Suppression of Septoria tritici Blotch and Leaf Rust of Wheat by Recombinant Cyanide-Producing Strains of Pseudomonas putida. Mol. Plant-Microbe Interact. 1996, 9, 642. [CrossRef]

30. Faramarzi, M.A.; Brandl, H. Formation of water-soluble metal cyanide complexes from solid minerals byPseudomonas plecoglossicida. FEMS Microbiol. Lett. 2006, 259, 47-52. [CrossRef]

31. Brandl, H.; Lehmann, S.; Faramarzi, M.A.; Martinelli, D. Biomobilization of silver, gold, and platinum from solid waste materials by HCN-forming microorganisms. Hydrometallurgy 2008, 94, 14-17. [CrossRef]

32. Kržanović, D.; Conić, V.; Bugarin, D.; Jovanović, I.; Božić, D. Maximizing Economic Performance in the Mining Industry by Applying Bioleaching Technology for Extraction of Polymetallic Mineral Deposits. Minerals 2019, 9, 400. [CrossRef]

(C) 2019 by the authors. Licensee MDPI, Basel, Switzerland. This article is an open access article distributed under the terms and conditions of the Creative Commons Attribution (CC BY) license (http://creativecommons.org/licenses/by/4.0/). 